\title{
Effect of a single application of coumestrol and/or dimethyl sulfoxide, on sex hormone levels and vaginal cytology of anestrus bitches
}

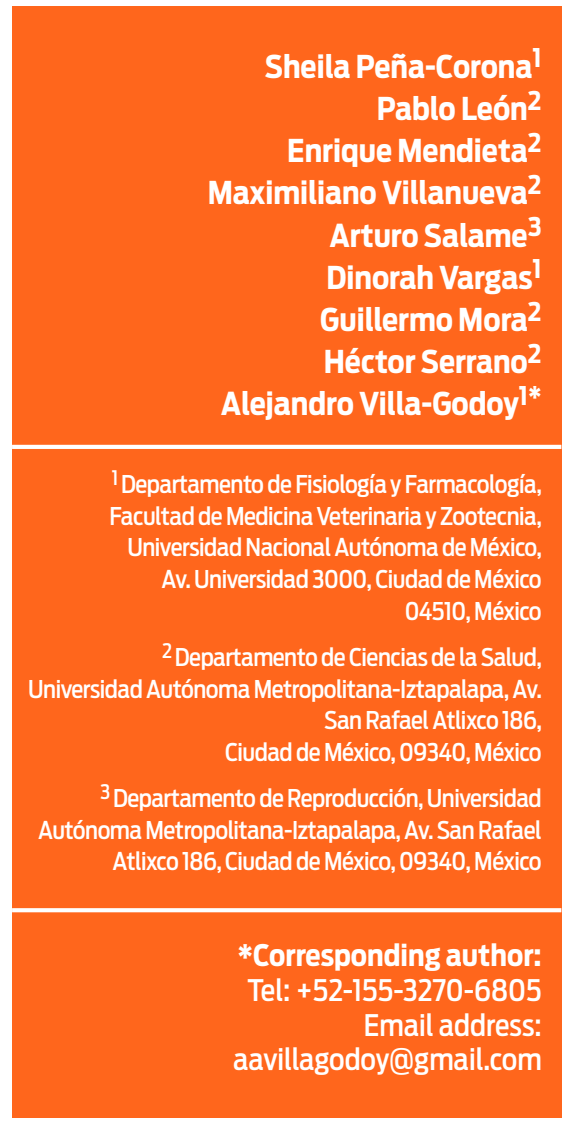

Accepted: $2018-12-04$ Published: 2019-03-22

Additional information and declarations can be found on page 12

(c) Copyright 2019 Sheila Peña-Corona et al. open access $\boldsymbol{\gamma}$

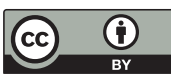

Distributed under Creative Commons CC-BY 4.0

\begin{abstract}
Canine overpopulation continues to be a problem with serious public health implications, despite a diversity of programs and strategies that have been implemented for its control. Coumestrol (COU) is an organic compound with estrogenic activity, thus having the potential to alter reproduction in mammals. COU is commonly dissolved in dimethyl sulfoxide (DMSO) before administration; however, evidence indicates that DMSO is not inert. The aim of this study was to assess the effects of either a single oral administration of COU diluted in DMSO or of DMSO-alone, on serum progesterone (P4) and estradiol (E2), on vaginal cell pattern, and on anestrus and diestrus lengths in bitches. Fifteen anestrus female dogs received either a single commercial dog food biscuit (Control, $\mathrm{n}=5$ ), a biscuit with $600 \mu \mathrm{g}$ of COU/kg diluted in $20 \mu \mathrm{L}$ of DMSO (COU, $n=5$ ), or a biscuit with $20 \mu \mathrm{L}$ of DMSO (DMSO, $n=5$ ). Circulating P4, E2, and changes in vaginal cytology, were assessed within the first month after treatment administration. Hormone levels were also measured from months 2-6 post-treatment. Mean differences were analyzed by the GLM procedure for repeated measures. COU enhanced serum E2 levels, and DMSO increased serum P4, number of vaginal anucleated superficial cells, and diestrus length. All dogs were deemed healthy based on all periodical clinical exams, but abnormal mammary gland growth and/or galactorrhea were observed in two COU and one DMSO-treated bitches. The findings of the present study expose the need to reevaluate previous reports of use of $\mathrm{COU}$ in bitches, and perhaps in other mammals.
\end{abstract}

Keywords: Coumestrol, dimethyl sulfoxide, estradiol, progesterone, vaginal cytology, bitches.

\section{Cite this as:}

Peña-Corona S, León P, Mendieta E, Villanueva M, Salame A, Vargas D, Mora G, Serrano $\mathrm{H}$, Villa-Godoy A. Effect of a single application of coumestrol and/or dimethyl sulfoxide, on sex hormone levels and vaginal cytology of anestrus bitches. Veterinaria México OA. 2019;6(1) doi: 10.22201/fmvz.24486760e.2019.1.656. 


\section{Introduction}

Dogs have had a close and positive relationship with humans for approximately 15,000 years. ${ }^{1,2}$ However, worldwide canine overpopulation has increasingly turned into a serious public health problem, particularly in underdeveloped countries. 3,4

Several programs and strategies have been implemented to control this problem. However, these have mostly been insufficient or unsuccessful, due to attached economic, ethical and/or social constraints. 5,6 Thus, there is a need to continue searching for adequate alternatives to control canine reproduction.

The bitch is the only domestic animal that has an anestrus stage considered within the estrous cycle, which lasts between two and six months. During early and mid-anestrus, the hypothalamus and ovaries of bitches are relatively inactive. However, this condition changes during late anestrus, when there is an increase in expression of genes encoding for estrogen receptors, and for the P450 aromatase enzyme, which enhance estrogen biosynthesis in preparation for a new estrous cycle. ${ }^{7}$ Both estradiol (E2) and progesterone (P4) have fundamental roles in periodicity of the estrous cycles in bitches. ${ }^{8}$

Coumestrol (COU) molecules can bind to and activate estrogenic receptors (ER) $\alpha$ and $\beta$, thus mimicking estrogenic actions. Administration of COU has been reported to enhance proliferation of uterine and vaginal epithelia, as well as to reduce fertility in mares, cows, female bats, ewes, and rats. ${ }^{9-14}$

In mice, bitches, and male dogs, use of COU has been assessed as a treatment for controlling reproduction. ${ }^{15-17} \mathrm{COU}$ is commonly diluted in dimethyl sulfoxide (DMSO) before administration. However, DMSO may independently influence reproduction in mammals, since it has been shown to modulate estrogenic responses in hepatocytes of fish, ${ }^{18,19}$ and to induce cell differentiation of rat mammary glands. ${ }^{20}$ Indeed, previous results from our lab show that COU and/or DMSO are estrogenic when administered to periovulatory stage bitches. ${ }^{15}$ In fact, peripheral levels of both P4 and E2 were modified, and numbers of cornified vaginal cells were increased. Nonetheless, to the best of our knowledge, there have been no studies where administration of COU and/or DMSO during a non-estrogenically susceptible stage (such as anestrus in bitches) has been assessed.

Thus, our hypothesis was that both COU and DMSO would increase circulating E2 levels, decrease peripheral P4, and alter vaginal cell types in anestrus bitches, without affecting diestrus or anestrus lengths. Therefore, our first aim was to evaluate the effects of a single oral administration of COU diluted in DMSO or of DMSO-alone, on the above-mentioned variables, whilst a second objective was to clinically assess the effects of these treatments on health status of experimental dogs.

Our findings show for the first time that DMSO by itself has estrogenic effects in anestrus bitches. Therefore, results of earlier studies where estrogenic actions were attributed to COU when diluted in DMSO should be re-examined.

\section{Materials and methods Ethical review}

All procedures complied with the Mexican Official Regulation NOM-062-ZOO-1999, under protocol number DC-2015 / 2-10 for the Production, Care and Use of Labo- 
ratory Animals. A written consent was provided by dog owners for the inclusion of their animals in this research.

\section{Animals and general management}

Fifteen sexually mature bitches, which remained at their owner's house throughout the study, were used. Individual animals were given different brands of commercial dry dog food (kibbles), occasionally complemented with household meal leftovers. Bitches also had free access to water. Housing and general care of animals were deemed adequate by researcher inspection prior to the start of the trial. Bitches had health cards and a history of regular visits to a veterinary center. Proper internal and external parasite control, as well as vaccination against leptospira, distemper, adenovirus, parvovirus, parainfluenza, and rabies were confirmed. In addition, a clinical visit by a qualified veterinarian was scheduled the beginning of the trial to establish an adequate health status. A complete blood cell count test was also used to evaluate overall health of bitches. In addition, animals had not been diagnosed with any disease or received any antibacterial medication during the six months preceding the beginning of the study. Fifteen sexually mature (4.53 \pm 1.80 years old) intact bitches that had been in estrus at least once were used. Animals weighed $8 \pm 4.29 \mathrm{~kg}$ and were all from small-to-medium size breeds (5Poodles; 3 Schnauzers; 2 Pugs; 1 Yorkshire; 4 mixed-breed dogs). Bitches were in anestrus at the beginning of the experiment, as determined by waiting for a 2-3 months period subsequent to estrus detection. In addition, a vaginal smear (EVC) was taken to confirm a cell pattern typical to anestrus. ${ }^{22}$

\section{Treatments}

Animals were randomly assigned to one of the following treatments: 1) Control group $(n=5)$, in which bitches received a single commercial dog food biscuit (Pedigree ${ }^{\circledR}$ ) with no additives at the beginning of the study (day 0); 2 ) COU-treated group ( $n=5)$, where animals received a single biscuit instilled with COU $(600 \mu \mathrm{g} / \mathrm{kg}$ of body weight; Sigma Chemical Co. St. Louis, Mo, USA) which was diluted with DMSO (20 $\mu \mathrm{L}$ per $600 \mu \mathrm{g}$ of COU; Sigma Chemical Co. St. Louis, Mo, USA, 99.9\% purity); and 3) DMSO-treated group ( $\mathrm{n}=5)$, where a biscuit that contained only DMSO (20 $\mu \mathrm{L} / \mathrm{kg}$ of body weight) was given to bitches. All animals were weighed prior to treatment delivery, and appropriate doses for each individual were infused to the center of a biscuit by means of a 10-100 $\mu \mathrm{L}$ micropipette. Biscuits were left for between 10 and 15 min after drug infusion, to ensure compounds were well absorbed prior to delivery. Complete ingestion of biscuits was also verified. The chosen dose of COU had been previously tested in male dogs. ${ }^{23}$ DMSO quantity $(20 \mu \mathrm{L})$ was set at the minimum required for adequate dilution of $600 \mu \mathrm{g}$ of $\mathrm{COU}$ (without the need of vortexing or heating), that had been approved by the Food and Drug Administration (FDA) for dogs. ${ }^{24}$ 


\section{Biological samples}

Hormones

Blood was drawn from cephalic veins on days $0,14,21$, and 28 post-treatment, as well as every 30 days for an additional 6-month period. P4 and E2 were measured in serum by immune-enzymatic assays (Enzyme-Linked Immune-Absorbent Assay, DGR Instruments, GmbH, Germany). The assay curve for E2 and for P4comprised values from 10.6 to $2000 \mathrm{pg} / \mathrm{mL}$ and 0.01 to $40 \mathrm{ng} / \mathrm{mL}$ respectively.

EVC

A vaginal smear was taken from the caudal portion of the vagina on days 0,7 , 14, 21 and 28. Cells were transferred by rolling the swab onto a glass slide, fixed with Citospray (CTR Scientific, Mexico), and stained using a modified Papanicolaou procedure (by using saline solution instead of distilled water), to preserve erythrocytes. ${ }^{25}$ Parabasal, intermediate, and superficial (nucleated and anucleated) vaginal cells were counted by optical microscopy with a 40x objective (one randomly chosen slide per animal; Axio Scope.A1, Zeiss, Mexico).

\section{Anestrus and diestrus duration}

Owners were taught to identify and then report signs of estrous. Beginning of diestrus was retrospectively established as the day following disappearance of estrus signs with P4 levels over $2.5 \mathrm{ng} / \mathrm{mL}$. The end of diestrus was established as the day when P4 had fallen under $2.5 \mathrm{ng} / \mathrm{mL}$ in at least two consecutive samples. The $2.5 \mathrm{ng} / \mathrm{mL}$ point between diestrus and anestrus was set from a maximum previously observed $\mathrm{P} 4$ level of $2 \mathrm{ng} / \mathrm{mL}$ in anestrus bitches ${ }^{26}$. Assay sensitivity for P4 assays allowed to statistically distinguish $2.0 \mathrm{ng} / \mathrm{mL}$ from $2.5 \mathrm{ng} / \mathrm{mL}$ in standard curves $(P<0.05$, regression analysis). Beginning of anestrus was established as the day following end of diestrus.

\section{Design and statistical analysis}

Serum E2 and P4 levels and vaginal cell counts for the first 28 days of the study, as well as hormone concentrations between months 2 and 6 were analyzed by ANOVA in a completely randomized design for repeated measures (PROC GLM, SAS, version 9.3; SAS Ins. Inc., Cary, NC, USA). The statistical model included the effects of treatment, animal nested within treatment, day, and treatment by day. The Tukey-Kramer test was used for post-hoc mean contrasts. Length of anestrus and diestrus was analyzed by ANOVA (GLM,SPSS Statistics, version 24, IBM, USA], and the post-hoc Bonferroni test.

\section{Results and discussion}

Hormones

Levels of serum P4 remained constant during the first 28 days post-treatment in control and COU groups (Figure 1A). This result is in contrast to a previous work ${ }^{15}$ where administration of COU significantly reduced $\mathrm{P} 4$ on days 21 and 28 post-treatment in periovulatory stage bitches. However, serum P4 levels found in this study 


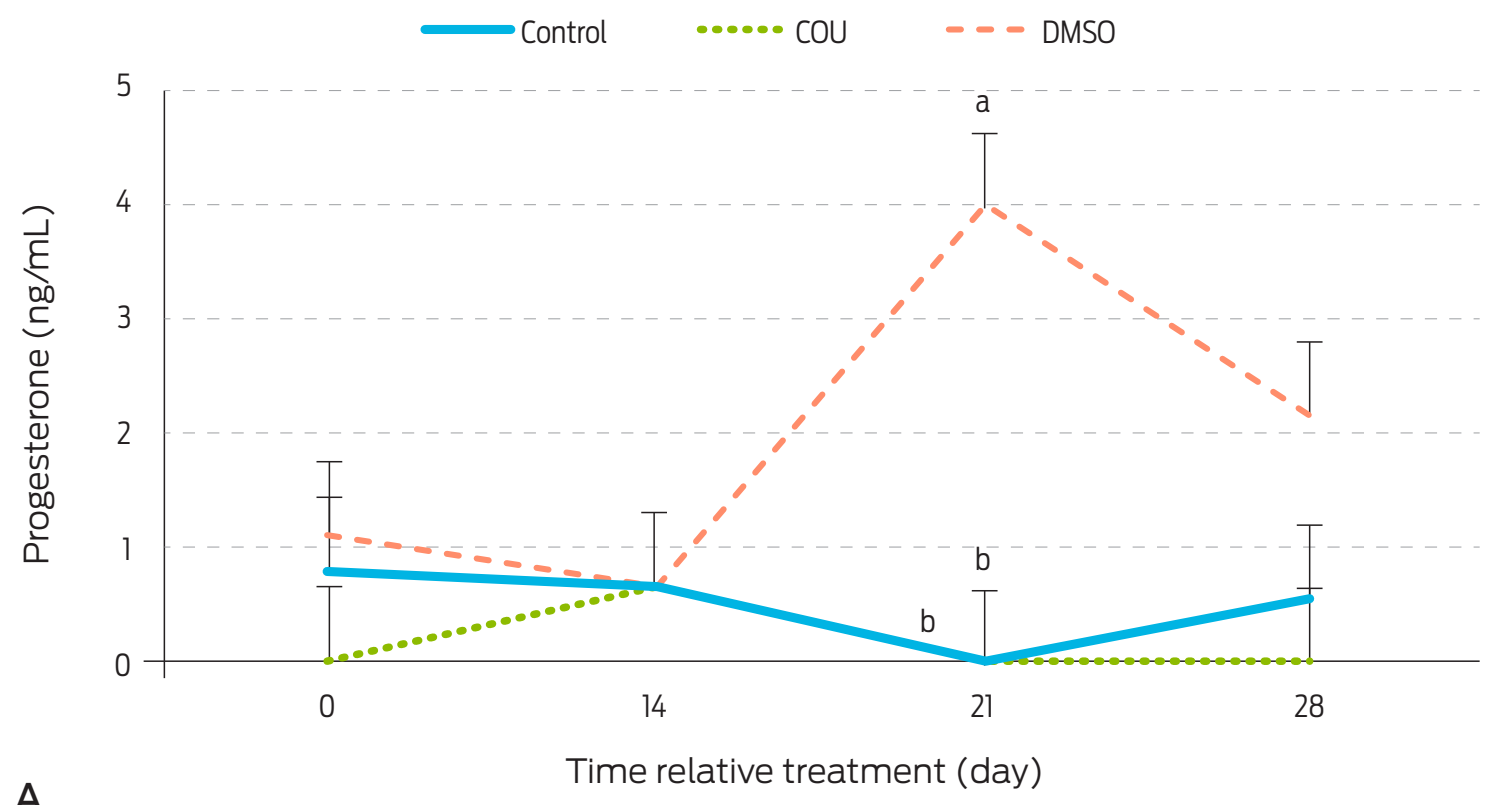

A

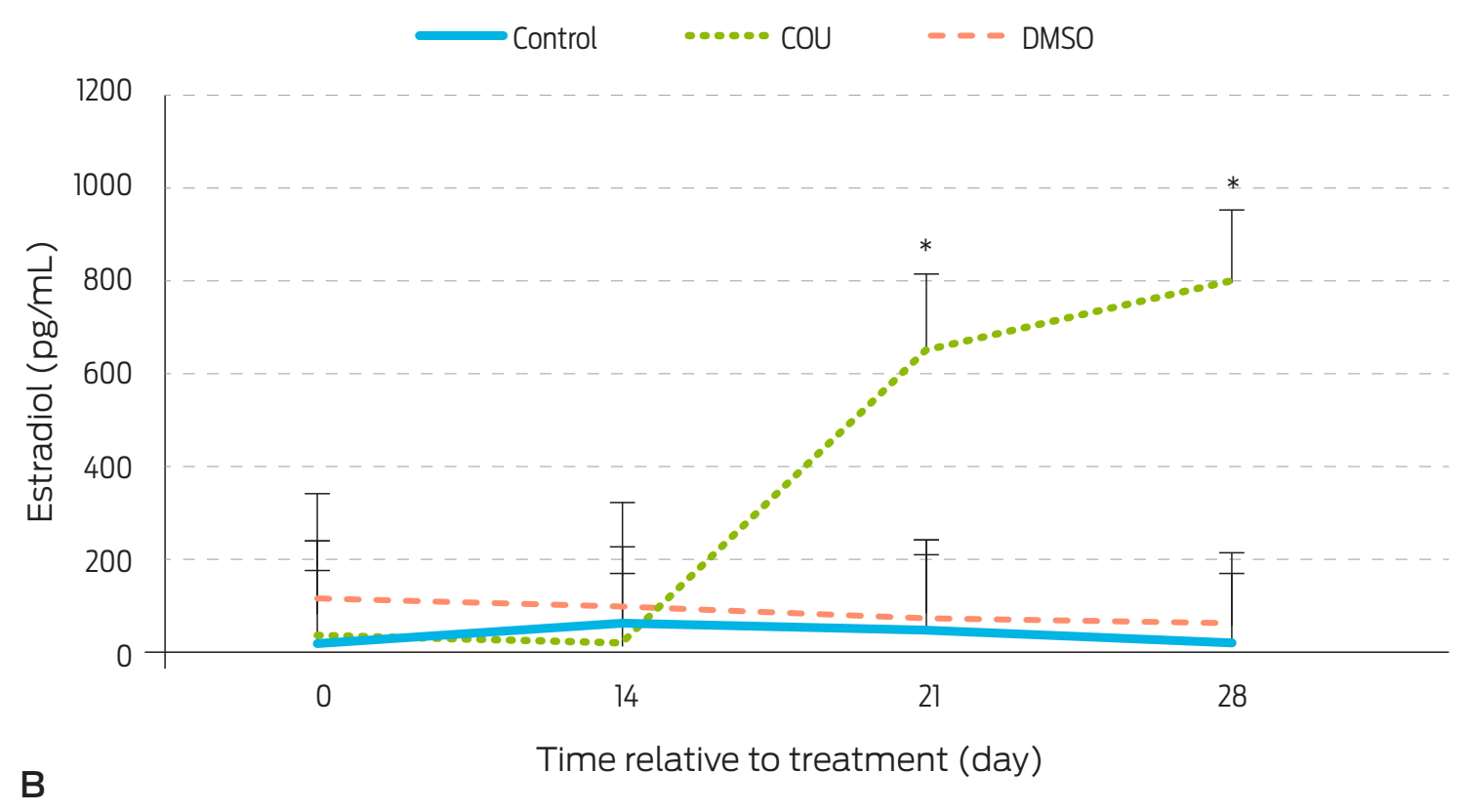

Figure 1. Progesterone (A) and estradiol (B) serum levels in anoestrous bitches receiving a commercial dog food biscuit alone (Control; $n=5)$, a biscuit with coumestrol diluted in dimethyl sulfoxide (COU; $n=5)$, or a biscuit with only dimethyl sulfoxide (DMSO; $n=5)$. a,b Different letters within sampling day indicate difference between treatments $(P<0.05)$. *specifies statistical increase on post-treatment days $21(\mathrm{P}<0.0048)$ and 28 (0.0008). Data are presented as LSM \pm standard error. 
were basal to begin with, which could explain this difference. Alternatively, COU effects on P4 may be stage-dependent. To our knowledge, there have been no other published studies where COU had been given to bitches, however, stage-dependant effect of COU have been reported in other animal models. Indeed, addition of $\mathrm{COU}$ to luteal cell cultures did not affect $\mathrm{P} 4$ secretion $^{27}$ in samples from pregnant cows, but levels were increased on samples from days 16-19 of the estrous cycle, or decreased on luteal cells from days 11-15.28

Serum E2 levels were increased by COU administration on days 21 and 28 after treatment (Figure 1B). This contrasts with findings in COU treated periovulatory stage bitches were E2 remained constant. ${ }^{15}$ Dycotomic effects of COU on other hormones and animal models have also been observed. COU given orally to ovariectomized ewes for instance, decreased amplitude of $\mathrm{LH}$ pulses during the breeding season, but not during anestrus. ${ }^{29}$ Similarly, COU increased E2 secretion from granulosa cells collected from small ovarian follicles $(<1 \mathrm{~cm})$ of cows and heifers, but this effect was not observed when cells were obtained from larger follicles. ${ }^{28}$

An increase in serum concentrations of P4 on day 21 post-treatment ( $P=0.0038$ ) was seen in DMSO group bitches (Figure 1A). Therefore, DMSO seems to exert a progestogenic effect in anestrus bitches that had not been seen in studies with periovulatory dogs, where a similar dose of DMSO was given. However, DMSO was reported to decrease P4 concentrations from day 21 to 28 post-treatment in periovulatory bitches ${ }^{15}$. Thus, a stage-dependent effect of DMSO on P4 secretion may also be possible, although no related studies were found for other mammal species.

DMSO did not alter E2 levels during the first 28 days post-treatment (Figure 1B). This contrasts to findings in periovulatory bitches, where the same dose of DMSO increased circulating E2 on day 21 after administartion ${ }^{15}$, again suggesting a stage-dependent effect. There is evidence in animals other than mammals, of DMSO-mediated effects on E2 receptors (ER). Indeed, DMSO stimulates ER $\alpha$ and ER $\beta$ in salmon hepatocytes. ${ }^{19}$ StAR and P450scc enzymes are also affected by DMSO in rat brain and kidneys. ${ }^{30}$

Levels of P4 and E2 remained constant and did not differ between groups from the second to the sixth post-treatment months (Table 1). This suggests that even when there is a delayed effect of COU and/or DMSO administration (first detected on day 21 post-treatment), this effect is relatively short, since no changes in hormone levels were observed beyond day28. In particular for COU, this result could relate to an interaction between $\mathrm{COU}$ and the ER. ${ }^{32}$ There is no evidence of DMSO binding to ERs but it can increase ER $\alpha$ and ER $\beta$ in salmon hepatocytes, ${ }^{19}$ thus it may have direct or indirect actions through the E2 pathway.

\section{Vaginal cells}

A single administration of $\mathrm{COU}$ did not affect types (Table 2) or numbers (Figure 2) of vaginal cells in anestrus bitches; whereas number of parabasal cells was reduced and that of superficial anucleated cells increased in periovulatory animals ${ }^{15}$. Again, this difference could come down to the stage of the estrous cycle when treatment was applied. However, this may not be the case ${ }^{15}$ for other species. COU and other phytoestrogens induce a cornification of the vaginal epithelium that is independent of reproductive status or age in rodents. Similarly, observed changes in vaginal 
Table 1. Serum levels of progesterone and estradiol in anestrus bitches from the second to the sixth month after treatment.

\begin{tabular}{|c|c|c|c|c|c|c|}
\hline & & & & $h$ after treat & & \\
\hline Hormone & Group & 2 & 3 & 4 & 5 & 6 \\
\hline & Control & $9.4 \pm 4.9$ & $39.7 \pm 23.4$ & $50.9 \pm 29.2$ & $24.1 \pm 12.9$ & $5.3 \pm 5.0$ \\
\hline P4 (ng/mL) & $\mathrm{COU}$ & $15.5 \pm 6.5$ & $6.8 \pm 2.8$ & $18.3 \pm 11.2$ & $3.3 \pm 1.4$ & $0.3 \pm 0.1$ \\
\hline & DMSO & $25.3 \pm 19.0$ & $18.8 \pm 10.8$ & $3.4 \pm 1.2$ & $52.2 \pm 24.2$ & $3.1 \pm 1.3$ \\
\hline & Control & $33.8 \pm 15.1$ & $38.5 \pm 17.3$ & $45.1 \pm 20.2$ & $53.9 \pm 24.1$ & $39.1 \pm 17.5$ \\
\hline E2 $(\mathrm{pg} / \mathrm{mL})$ & $\mathrm{COU}$ & $14.8 \pm 5.3$ & $52.8 \pm 15.5$ & $49.5 \pm 5.3$ & $42.8 \pm 8.1$ & $34.2 \pm 4.4$ \\
\hline & DMSO & $246.7 \pm 196.4$ & $39.5 \pm 25.6$ & $12.8 \pm 1.5$ & $72.2 \pm 34.6$ & $68.6 \pm 34.8$ \\
\hline
\end{tabular}

Serum levels of progesterone (P4), and estradiol (E2) in anestrus bitches given a single commercial dog food biscuit (Control, $n=5$ ); a single biscuit with coumestrol dissolved in dimethyl sulfoxide $(\mathrm{COU}, \mathrm{n}=5)$ or a single biscuit with only dimethyl sulfoxide

(DMSO, $n=5$ ). Data are presented as mean \pm standard error.

Table 2. Proportion of vaginal cell type in anestrus bitches treated with coumestrol and/or dimethyl sulfoxide.

\begin{tabular}{|c|c|c|c|c|c|}
\hline \multirow{3}{*}{ Day } & \multirow{3}{*}{ Group } & \multicolumn{4}{|c|}{ Vaginal cells } \\
\hline & & \multirow[b]{2}{*}{ Parabasal } & \multirow[b]{2}{*}{ Intermediate } & \multicolumn{2}{|c|}{ Superficial } \\
\hline & & & & Nucleated & Anucleated \\
\hline \multirow[t]{3}{*}{0} & Control & $46.4 \pm 5.6$ & $21.6 \pm 1.4$ & $13.5 \pm 2.1$ & $18.5 \pm 3.8$ \\
\hline & $\mathrm{COU}$ & $50.1 \pm 3.4$ & $24.1 \pm 5.6$ & $8.6 \pm 1.0$ & $17.6 \pm 6.1$ \\
\hline & DMSO & $45.4 \pm 1.6$ & $32.8 \pm 6.5$ & $18.4 \pm 5.8$ & $4.5 \pm 1.7$ \\
\hline \multirow[t]{3}{*}{7} & Control & $41.1 \pm 2.2$ & $32.6 \pm 1.5$ & $10.1 \pm 0.4$ & $16.2 \pm 2.5$ \\
\hline & $\mathrm{COU}$ & $45.8 \pm 1.1$ & $20.3 \pm 7.0$ & $13.7 \pm 1.7$ & $20.6 \pm 7.0$ \\
\hline & DMSO & $49.1 \pm 3.1$ & $30.9 \pm 5.3$ & $17.4 \pm 4.6$ & $5.1 \pm 2$ \\
\hline \multirow[t]{3}{*}{14} & Control & $54.3 \pm 5.1$ & $23.7 \pm 3.1$ & $9.8 \pm 3.5$ & $12.1 \pm 2.4$ \\
\hline & $\mathrm{COU}$ & $47.0 \pm 1.7$ & $22.5 \pm 7.7$ & $13.1 \pm 2.2$ & $18.2 \pm 9.0$ \\
\hline & DMSO & $52.8 \pm 5.0$ & $29.1 \pm 4.8$ & $16.4 \pm 3.9$ & $5.7 \pm 2.4$ \\
\hline \multirow[t]{3}{*}{21} & Control & $49.5 \pm 5.0$ & $30.4 \pm 6.6$ & $12.3 \pm 4.3$ & $8.8 \pm 7.9$ \\
\hline & $\mathrm{COU}$ & $48.9 \pm 1.5$ & $24.6 \pm 6.7$ & $16.6 \pm 2.8$ & $10.9 \pm 5.6$ \\
\hline & DMSO & $50.8 \pm 6.8$ & $23.2 \pm 6.8$ & $26.8 \pm 7.8$ & $5.6 \pm 3.5$ \\
\hline \multirow[t]{3}{*}{28} & Control & $51.1 \pm 4.7$ & $28.1 \pm 4.0$ & $9.9 \pm 4.1^{\mathrm{a}}$ & $10.8 \pm 1.6$ \\
\hline & $\mathrm{COU}$ & $49.5 \pm 3.7$ & $20.6 \pm 5.9$ & $13.3 \pm 4.6^{a}$ & $17.1 \pm 5.2$ \\
\hline & DMSO & $45.3 \pm 1.3$ & $20.0 \pm 6.1$ & $30.4 \pm 4.3^{b}$ & $6.3 \pm 4.5$ \\
\hline
\end{tabular}

Proportion of vaginal cell type in anestrus bitches given a single commercial dog food biscuit (Control, $n=5$ ); a biscuit with added coumestrol dissolved in dimethyl sulfoxide (COU, $n=5)$, or single biscuit with only dimethyl sulfoxide (DMSO, $n=5$ ). $\mathrm{a}, \mathrm{b}$ Different superscripts indicate difference within day $(\mathrm{P}=0.007)$. Data are presented as mean \pm standard error. 


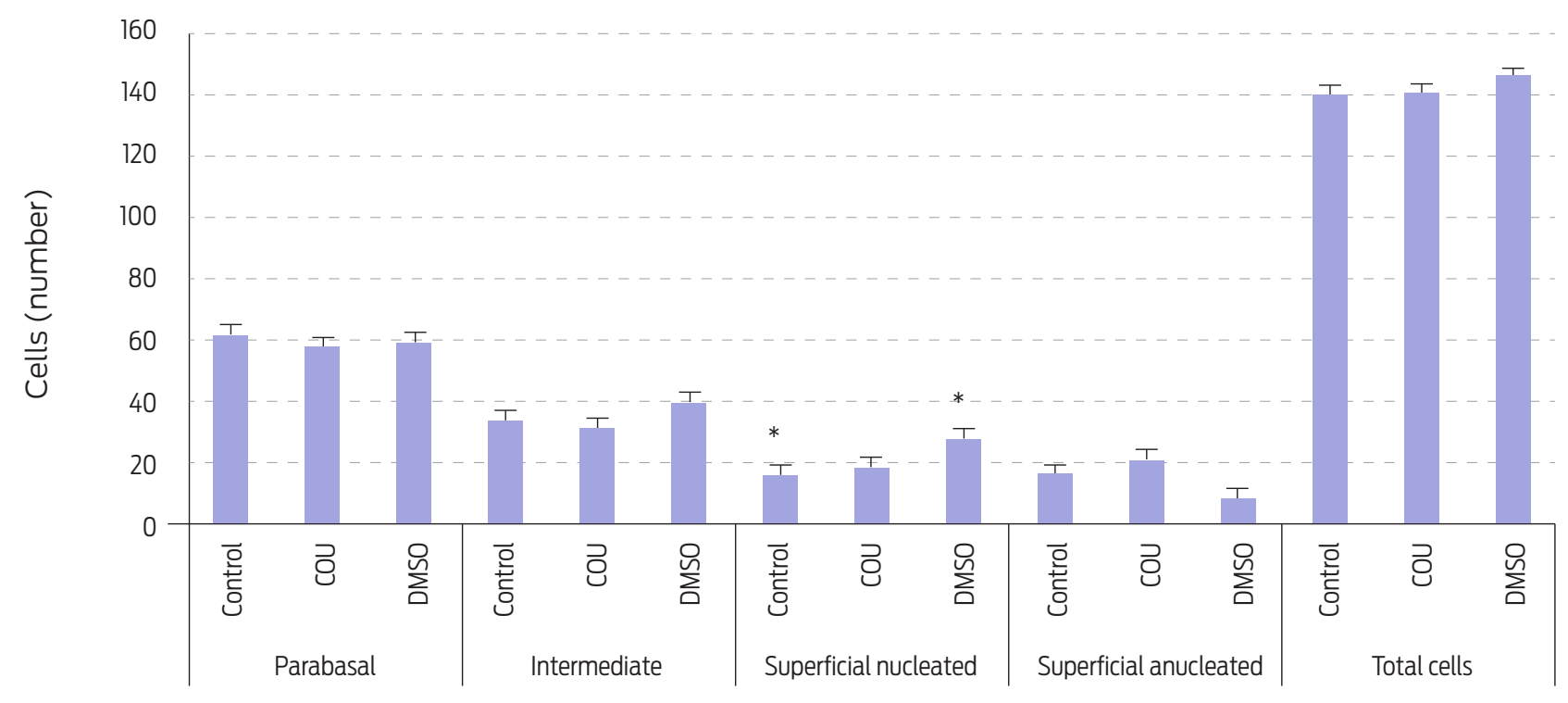

Type of cells and treatment

Figure 2. Vaginal cell type and number during the first 28 days post-treatment in anestrus bitches receiving a single commercial dog food biscuit (Control, $n=5$ ), a biscuit with added coumestrol dissolved in dimethyl sulfoxide (COU, $n=5)$, or a single biscuit with only dimethyl sulfoxide (DMSO, $n=5)$., Means sharing an asterisk within cell type differ $(\mathrm{P}=0.056)$. Data are presented as mean \pm standard error.

epithelium of women appeared to be more related to phytoestrogen consumption than to reproductive state. ${ }^{33}$

DMSO, when administered alone, did increase the number of superficial nucleated cells at day 28 post-treatment ( $\mathrm{P}=0.007$; Table 2$)$. In fact, superficial nucleated cell number was higher during the post-treatment day 28 in DMSO treated animals than in any of the other groups ( $(\mathrm{P}=0.056$; Figure 2$)$. Thus, DMSO showed an estrogenic effect in vaginal cells without an observed increase in either P4 or E2 serum levels. An enhanced number of parabasal cells after DMSO administration has been reported in periovulatory stage bitches. ${ }^{15}$ Hence, DMSO may have different effects on vaginal epithelium according to the stage of the estrous cycle at which it is given.

\section{Diestrus and anestrus lengths}

Length of anestrus was not affected by treatment (Figure 3). However, diestrus was longer in the DMSO group when compared to control $(\mathrm{P}=0.060)$ or $\mathrm{COU}$ $(\mathrm{P}=0.018)$ treated animals.. The physiological mechanism to explain this result, was not assessed in this study. However, since DMSO increased serum levels of P4 on day 21 post-treatment, a cystic-like effect could have been induced which may have prolonged diestrus.

\section{Health and side effects}

At the beginning of the study all bitches were deemed as healthy after clinical examination, and all blood parameters were within reference values. No health or 


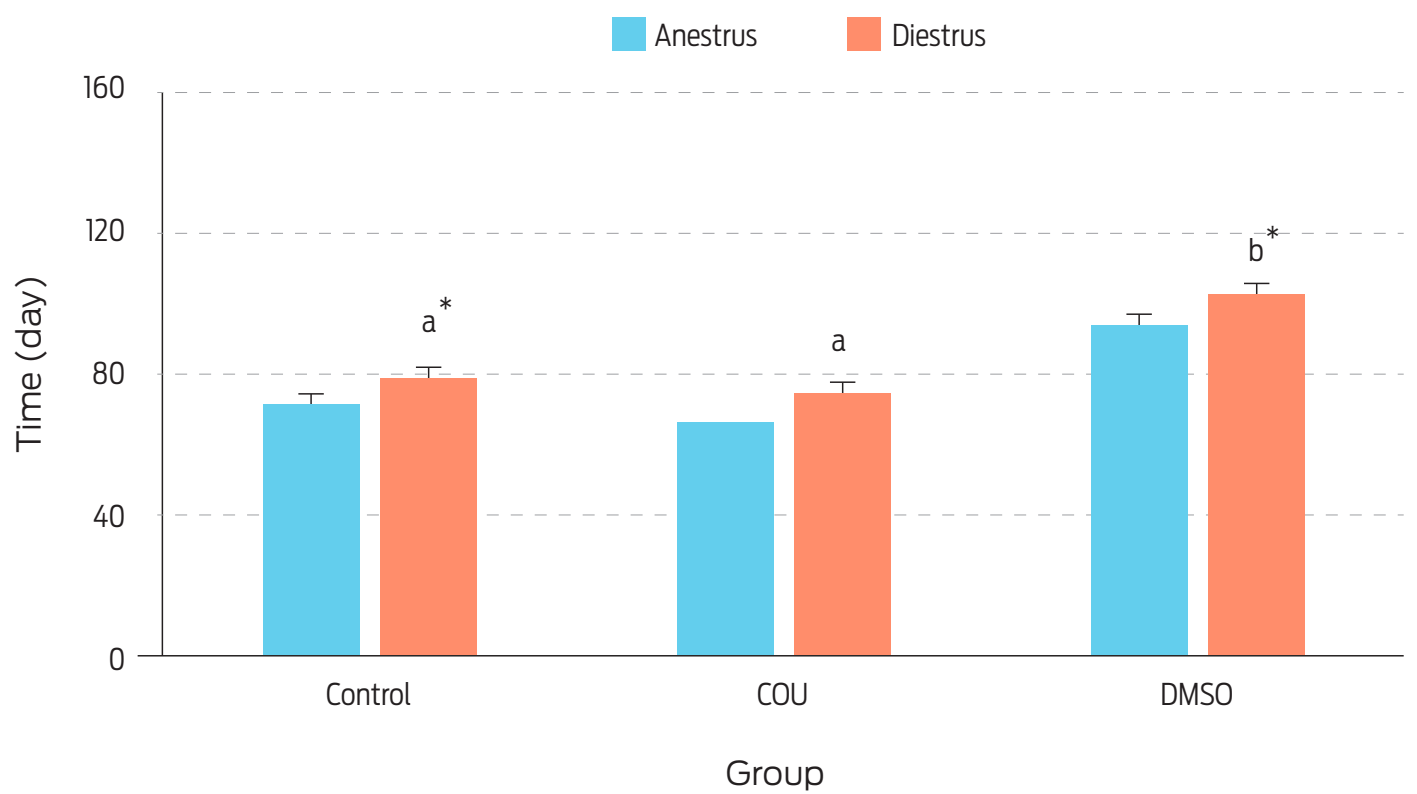

Figure 3. Length of anestrus and diestrus (days) on bitches receiving a single commercial dog food biscuit (Control, $n=5$ ), a single biscuit with added coumestrol dissolved in dimethyl sulfoxide ( $\mathrm{COU}, \mathrm{n}=5)$, or a single biscuit with dimethyl sulfoxide alone (DMSO, $n=5)$. ${ }^{a}$ b Different superscripts indicate difference between treatments $(P=0.018)$., Means sharing an asterisk within groups differ $(\mathrm{P}=0.060)$. Data are presented as Least square means \pm standard error.

behavioral alterations were observed in any of the animals during the six-month trial period. This coincides with previous work where COU and DMSO treated periovulatory-stage bitches were found healthy throughout the study, and had normal blood panels six months after treatment. ${ }^{15}$ Thus, a single oral administration of COU and/ or DMSO does not appear to negatively affect health status of treated bitches. However, two of the COU-treated animals, showed abnormal mammary gland growth and galactorrhea during the third month after treatment which endured for close to 15 days (bitches identified as COU-3 and COU-5; Figure 4). Furthermore, an animal from the DMSO treatment group (bitch DMSO-4), showed galactorrhea, with no apparent mammary growth on month 6 post-treatment. In addition, a dog from the DMSO group (DMSO-5) had serum P4 levels $\geq 3.7 \mathrm{ng} / \mathrm{mL}$, which lasted for at least six months. The side effects of phytoestrogens on mammary gland have been documented before in ovariectomized macaques, 35 and reports indicate that DMSO can induce differentiation of mammary cells from rats. ${ }^{20}$ This unwanted side effect should be thought about if inclusion of COU or DMSO is to be considered in reproductive control programs. The induced abnormal mammary gland development and galactorrhea were not considered as signs of disease in this study, since use of estrogenic compounds combined with $\mathrm{P} 4$ is frequent to induce lactations in infertile ruminants, ${ }^{36-38}$ in non-human primates ${ }^{39}$ and in human surrogate pregnancies. ${ }^{40}$ Moreover, care was taken to instruct the owners on how to check for behavioral changes typical of pseudopregnancy, such as circling, digging or nesting, but none were seen in any of the bitches presenting with mammary alterations in size and/or function (Figure 4). ${ }^{26}$ Finally, dogs that showed abnormal mammary development and galactorrhea also had low serum P4 levels, which does not agree with the relatively high concentrations of the hormone that are usually seen with pseudopregnancy. ${ }^{41}$ Thus, it would be unlikely to induce pseudopregnancy with 
A
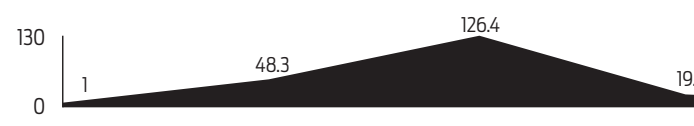

19.8

0.6

Vol. 6 I No. 1 I January-March I 2019
Control 1
Control 2
Control 3
Control 4
Cou 4
Control 5
COU1 2

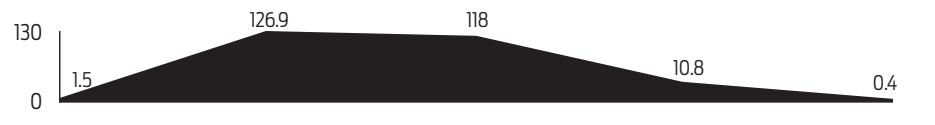

Vol. 6 I No. 1 I January-March I 2019
Control 1
Control 2
Control 3
Control 4
COU 5
Control 5
COU 1

${ }^{130} \mid 21.4$

0

0

0.1

Vol. 6 I No. 1 I January-March I 2019
Control 1
Control 2
Control 3
Control 4
COU 5
Control 5
COU 4
CoU 3

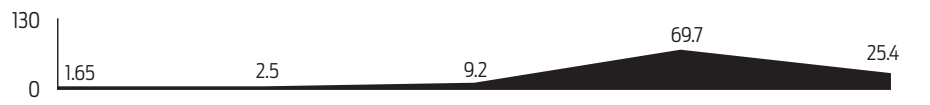

Vol. 6 I No. 1 I January-March I 2019
Control 1
Control 2
Control 3
Control 4
COU 5
Control 5
COU 4
CoU 3

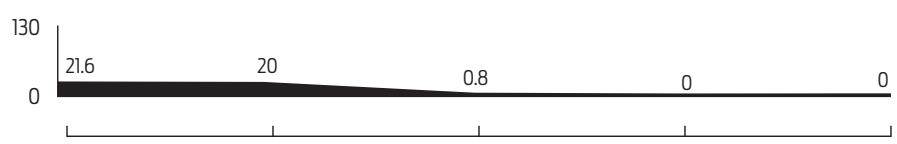

Vol. 6 I No. 1 I January-March I 2019
Control 1
Control 2
Control 3
Control 4
COU 5
Control 5
COU 1

B
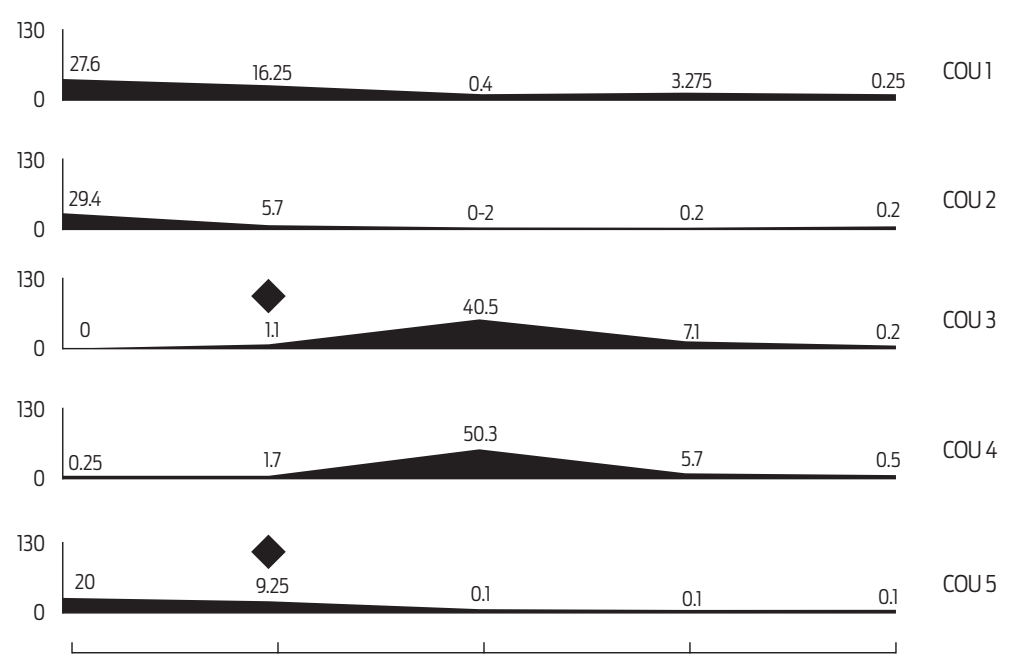

Vol. 6 I No. 1 I January-March I 2019
Control 1
Control 2
Control 3
Control 4
COU 5
Control 5
COU 4
CoU 3

C 130

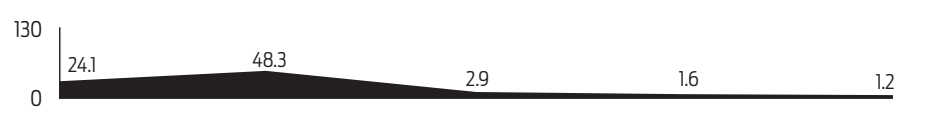

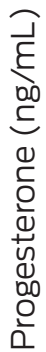
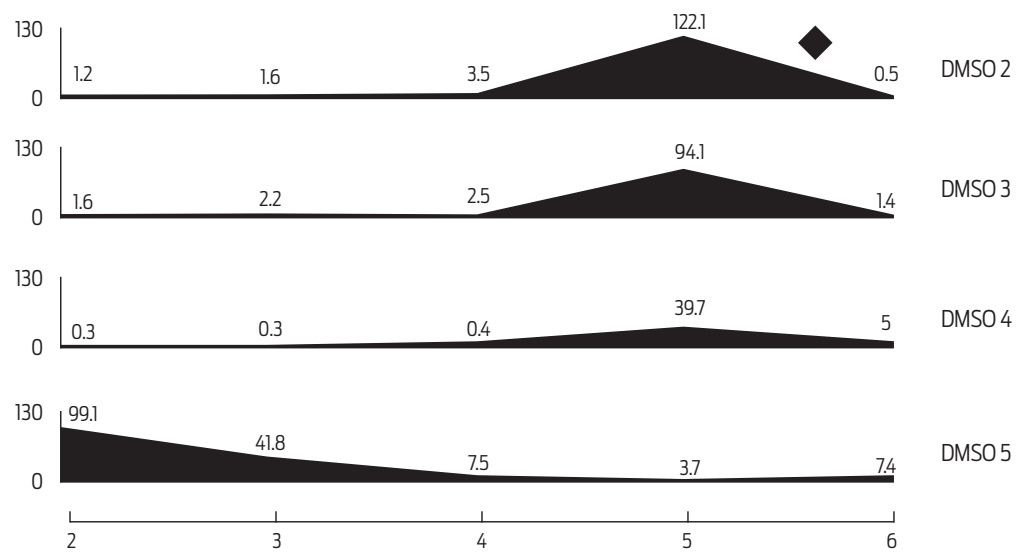

Time relative to treatment (month)

Figure 4. Serum progesterone profiles of individual bitches from months 2-6 post-treatment. A: untreated animals (Control; $\mathrm{n}=5)$. B: bitches receiving coumestrol diluted in dimethyl sulfoxide (COU; $n=5)$, and $\mathrm{C}$ : animals receiving dimethyl sulfoxide alone (DMSO; $n=5$ ). ( $\bullet$ Indicates dogs developing abnormal mammary gland growth and galactorrhea. 
either of the employed COU or DMSO doses. Nonetheless, even if there were no observed negative effects of COU and/or DMSO on health of bitches in this study, caution must be taken if frequency or dose of administration are increased, since there is evidence of induced health alterations with prolonged administration of $\mathrm{COU}$ in rodents and humans, ${ }^{14}$ and of DMSO in dogs, pigs and rodents ${ }^{42}$.

A shortcoming of this study was the impossibility of controlling animal diets. Dogs were given different brands of food and had diverse eating habits, which in some cases were even changed during the trial period. This made it impossible to track phytoestrogen content in given rations. However, as a reference, samples were collected from 24 different brands of commercial dog food that contained soy. Isoflavones such as genistein, daidzein, and glycitein were found, but not COU. ${ }^{46}$ We thus acknowledge that some amount of phytoestrogens may have been present in food and that this could have influenced our results. However, due to our findings regarding levels of P4 and E2, as well as on vaginal cytology patterns in control bitches, it is unlikely that the assumed presence of phytoestrogens was high enough to bias our data.

Since DMSO has been shown to have intrinsic estrogenic effects, reevaluation of studies in different mammals (such as bats, mice, and dogs) of effects previously attributed to COU (when diluted with DMSO) should be encouraged. 11,16,47 Further work to investigate the mechanisms of possible effects of DMSO on reproduction are also needed.

The idea of using $\mathrm{COU}$ as a potential alternative to control dog overpopulation has merit. However, its potential is hindered by the impossibility to separate COU and DMSO effects in our findings, and by the unwanted side effects observed in $40 \%(2 / 5)$ of the bitches. As for the use of DMSO alone, our evidence shows that can act as an endocrine disruptor in bitches, extending diestrus, enhancing vaginal cell proliferation and inducing galactorrhea in $20 \%$ of the dogs. Thus, use of COU and/or DMSO in reproductive control programs does not seem viable.

\section{Conclusions and repercussions}

Our results show that $\mathrm{COU}$ is estrogenic and inert in vaginal cells; and that DMSO increases P4 levels, enhances vaginal cell proliferation and prolongs diestrus length. Health of bitches was not altered by treatment, but COU and/or DMSO could induce abnormal mammary growth and/or galactorrhea. The main finding of this study is the profound effect that a single oral dose of DMSO can have on reproduction of female dogs. Reevaluation of effects attributed to COU (when diluted in DMSO) in this and previous reports is encouraged. 


\section{Funding}

This study was funded by the Universidad Autónoma Metropolitana, Grant number DCBS-14607008 and is part of the doctoral program of Sheila Irais Peña-Corona (supported by CONACYT scholarship 284232).

\section{Acknowledgements}

Authors wish to thank Ivonne Martínez, and Saúl Domínguez for their help in collecting biological samples and data.

\section{Conflicts of interest}

None of the authors have personal or financial relationships with organizations or people that could bias the content of this paper.

\section{Author contributions}

SP-C. Experimental design, conduction and coordination of the trial, data and biological sample collection, laboratory work, statistical analysis of data, and manuscript preparation.

$\mathrm{PL}$, AS, and $\mathrm{GM}$. Animal handling, assistance with data and biological sample collection.

MV. Clinical examination of animals.

EM and DV. Data analysis and performed a critical review of first draft.

HS. Experimental design.

AV-G. Amendment of experimental design, critical review of drafts, manuscript preparation and approval.

All authors read and approved the final manuscript.

\section{References}

1. Driscoll CA, Macdonald DW. Top dogs: wolf domestication and wealth. J Biol. 2010;9(2):10. doi: 10.1186/jbiol226.

2. Frantz LA, Mullin VE, Pionnier-Capitan M, Lebrasseur O, Ollivier M, Perri A, et al. Genomic and archaeological evidence suggest a dual origin of domestic dogs. Science. 2016;352(6290):1228-31. doi:10.1126/science.aaf3161.

3. Acha PN, Szyfres B. Zoonoses and communicable diseases common to man and animals. 3rd ed. Washington, D.C.: Pan American Health Organization; 2001. 395 p.

4. Taylor LH, Wallace RM, Balaram D, Lindenmayer JM, Eckery DC, Mutonono-Watkiss $\mathrm{B}$, et al. The role of dog population management in rabies elimination-a review of current approaches and future opportunities. Front Vet Sci. 2017;4:109. doi:10.3389/fvets.2017.00109.

5. Kutzler M, Wood A. Non-surgical methods of contraception and sterilization. Theriogenology. 2006;66(3):514-25. doi:10.1016/j.theriogenology.2006.04.014.

6. Munks MW. Progress in development of immunocontraceptive vaccines for permanent non-surgical sterilization of cats and dogs. Reprod Domest Anim. 2012;47 Suppl 4:223-7.

7. Okkens AC, Kooistra HS. Anoestrus in the dog: a fascinating story. Reprod Domest Anim. 2006;41(4):291-6. doi:10.1111/j.1439-0531.2006.00702.x.

8. Rehm S, Stanislaus DJ, Williams AM. Estrous cycle-dependent histology and review of sex steroid receptor expression in dog reproductive tissues and mam- 
mary gland and associated hormone levels. Birth Defects Res B Dev Reprod Toxicol. 2007;80(3):233-45. doi:10.1002/bdrb.20121.

9. Ferreira-Dias G, Botelho M, Zagrajczuk A, Rebordão MR, Galvão AM, Bravo PP, et al. Coumestrol and its metabolite in mares' plasma after ingestion of phytoestrogen-rich plants: potent endocrine disruptors inducing infertility. Theriogenology. 2013;80(6):684-92. doi:10.1016/j.theriogenology.2013.06.002.

10. Romero-R CM, Tarragó MR, Muñoz R, Arista R, Rosado A. Síndrome estrogénico en vacas lecheras por consumo de alfalfas con grandes cantidades de coumestrol. Vet Méx. 1997;28(1):25-30.

11. Serrano H, Pérez-Rivero JJ, Aguilar-Setién A, de-Paz O, Villa-Godoy A. Vampire bat reproductive control by a naturally occurring phytooestrogen. Reprod Fertil Dev. 2007;19(3):470-2.

12. Smith JF, Jagusch KT, Brunswick LFC, Kelly RW. Coumestans in lucerne and ovulation in ewes. New Zeal J Agr Res. 1979;22(3):411-16.

13. Whitten PL, Naftolin F. Effects of a phytoestrogen diet on estrogen-dependent reproductive processes in immature female rats. Steroids. 1992;57(2):56-61.

14. Whitten PL, Patisaul HB. Cross-species and interassay comparisons of phytoestrogen action. Environ Health Perspect. 2001;109 Suppl 1:5-20.

15. Peña-Corona $S$, Mendoza-Rodríguez CA, Martínez-Maya JJ, Salame A, León P, Mora $\mathrm{G}$, et al. Administration of coumestrol and/or dimethyl sulfoxide affects vaginal epithelium and sex hormones in bitches. Scientific Reports. 2018;SREP18-34696 peer review.

16. Pérez-Rivero JJ, Martínez-Maya JJ, Pérez-Martínez M, Aguilar-Setién A, Serrano $\mathrm{H}$. Efecto del coumestrol sobre la producción espermática y la conducta de exploración olfatoria de perros estimulados con moco vaginal estral. Vet. Méx. 2009;40(1):9-16.

17. Elias EA, Kincaid RL. Fertility of female mice fed coumestrol and diethylstilbestrol. J Environ Sci Health B. 1984;19(4-5):441-51. doi:10.1080/03601238409372442.

18. Lyssimachou A, Jenssen BM, Arukwe A. Brain cytochrome P450 aromatase gene isoforms and activity levels in atlantic salmon after waterborne exposure to nominal environmental concentrations of the pharmaceutical ethynylestradiol and antifoulant tributyltin. Toxicol Sci. 2006;91(1):82-92. doi:10.1093/toxsci/ kfj 136.

19. Mortensen AS, Arukwe A. Dimethyl sulfoxide is a potent modulator of estrogen receptor isoforms and xenoestrogen biomarker responses in primary culture of salmon hepatocytes. Aquat Toxicol. 2006;79(1):99-103. doi:10.1016/j. aquatox.2006.05.009.

20. Zucchi I, Bini L, Albani D, Valaperta R, Liberatori S, Raggiaschi R, et al. Dome formation in cell cultures as expression of an early stage of lactogenic differentiation of the mammary gland. Proc Natl Acad Sci U S A. 2002;99(13):8660-5. doi:10.1073/pnas.132259399.

21. NIH. National Heart, Lung, and Blood Institute. Blood test. [Internet]. 2018 [cited 2018 Nov 16]. Available from: https://www.nhlbi.nih.gov/health-topics/bloodtests - Types.

22. Post K. Canine vaginal cytology during the estrous cycle. Can Vet J. 1985;26(3):101-4. 
23. Gualo N. Efecto del coumestrol sobre la conducta sexual en perros (Canis familiaris) machos. [Master Thesis] México, D.F.: Universidad Nacional Autónoma de México; 2010.

24. FDA. Food and Drug Administration. CFR - Code of Federal Regulations Title 21: U.S. [Internet]. 2017 [cited 2018 Jan 16]. Available from: https://www.accessdata.fda.gov/scripts/cdrh/cfdocs/cfcfr/cfrsearch.cfm?cfrpart=524\&showfr=1.

25. Pérez CC, Rodríguez I, Dorado J, Hidalgo M. Use of ultrafast Papanicolaou stain for exfoliative vaginal cytology in bitches. Vet Rec. 2005;156(20):648-50.

26. Concannon PW. Reproductive cycles of the domestic bitch. Anim Reprod Sci. 2011;124(3-4):200-10. doi:10.1016/j.anireprosci.2010.08.028

27. Mlynarczuk J, Wrobel MH, Kotwica J. Adverse influence of coumestrol on secretory function of bovine luteal cells in the first trimester of pregnancy. Environ Toxicol. 2013;28(7):41 1-8. doi:10.1002/tox.20735

28. Mlynarczuk J, Wrobel MH, Kotwica J. The adverse effect of phytoestrogens on the synthesis and secretion of ovarian oxytocin in cattle. Reprod Domest Anim. 2011;46(1):21-8. doi:10.1111/j.1439-0531.2009.01529.x

29. Montgomery GW, Martin GB, Le Bars J, Pelletier J. Gonadotrophin release in ovariectomized ewes fed different amounts of coumestrol. J Reprod Fertil. 1985;73(2):457-63.

30. Lyssimachou A, Arukwe A. Alteration of brain and interrenal StAR protein, P450scc, and Cyp $11 \beta$ mRNA levels in atlantic salmon after nominal waterborne exposure to the synthetic pharmaceutical estrogen ethynylestradiol. J Toxicol Environ Health A. 2007;70(7):606-13. doi:10.1080/10937400600882905.

31. Finn CA, Martin L. Endocrine control of gland proliferation in the mouse uterus. Biol Reprod. 1973;8(5):585-8.

32. Zhao $\mathrm{E}, \mathrm{Mu} \mathrm{Q}$. Phytoestrogen biological actions on Mammalian reproductive system and cancer growth. Sci Pharm. 2011;79(1):1-20. doi:10.3797/ scipharm. 1007-15.

33. Burton JL, Wells $M$. The effect of phytoestrogens on the female genital tract. J Clin Pathol. 2002;55(6):401-7.

34. Knauf Y, Bostedt H, Failing K, Knauf S, Wehrend A. Gross pathology and endocrinology of ovarian cysts in bitches. Reprod Domest Anim. 2014;49(3):463-8. doi:10.1080/10937400600882905.

35. Foth $\mathrm{D}$, Cline JM. Effects of mammalian and plant estrogens on mammary glands and uteri of macaques. Am J Clin Nutr. 1998;68 6 Suppl:1413S-7S.

36. Mellado M, Bernal A, Mendoza R, Carrillo E. Hormonal induction of lactation in prepuberal and multiparous crossbred goats kept under extensive conditions. Small Ruminant Research. 1996;19(2):143-7.

37. Mellado M, Antonio-Chirino E, Meza-Herrera C, Veliz FG, Arevalo JR, Mellado J, et al. Effect of lactation number, year, and season of initiation of lactation on milk yield of cows hormonally induced into lactation and treated with recombinant bovine somatotropin. J Dairy Sci. 2011;94(9):4524-30.

38. García-Balcázar R, Plata-Rodríguez M, Díaz-Cruz A, Rodríguez-Hernández K, Hernández-Cerón J, Villa-Godoy A. Evaluation of oxidative stress in dairy goats lactating naturally or by hormonal induction. Tropical and Subtropical Agroecosystems. 2016;19(2):129-38.

39. Smith SD, Amos JD, Beck KN, Colvin LM, Franke KS, Liebl BE, et al. Refinement of a protocol for the induction of lactation in nonpregnant nonhuman 
primates by using exogenous hormone treatment. J Am Assoc Lab Anim Sci. 2014;53(6):700-7.

40. Biervliet FP, Maguiness SD, Hay DM, Killick SR, Atkin SL. Induction of lactation in the intended mother of a surrogate pregnancy: case report. Hum Reprod. 2001;16(3):581-3.

41. Steinetz BG, Goldsmith LT, Harvey HJ, Lust G. Serum relaxin and progesterone concentrations in pregnant, pseudopregnant, and ovariectomized, progestin-treated pregnant bitches: detection of relaxin as a marker of pregnancy. Am J Vet Res. 1989;50(1):68-71.

42. Noel PR, Barnett KC, Davies RE, Jolly DW, Leahy JS, Mawdesley-Thomas LE, et al. The toxicity of dimethyl sulphoxide (DMSO) for the dog, pig, rat and rabbit. Toxicology. 1975;3(2):143-69.

43. Woclawek-Potocka I, Mannelli C, Boruszewska D, Kowalczyk-Zieba I, Wasniewski T. Diverse effects of phytoestrogens on the reproductive performance: cow as a model. Int J Endocrinol. 2013;2013:650984. doi: 10.1155/2013/650984

44. Almstrup K, Fernández MF, Petersen JH, Olea N, Skakkebæk NE, Leffers H. Dual effects of phytoestrogens result in u-shaped dose-response curves. Environ Health Perspect. 2002;110(8):743-8.

45. Prince R, Draper C. Bone and calcium. In: Lobo R, Kelsey J, Marcus R, editors. Menopause: Biology and Pathobiology. New York: Academic Press; 2000. p. 287-307.

46. Cerundolo R, Court MH, Hao Q, Michel KE. Identification and concentration of soy phytoestrogens in commercial dog foods. Am J Vet Res. 2004;65(5):592-6.

47. Burroughs $C D$, Bern HA, Stokstad EL. Prolonged vaginal cornification and other changes in mice treated neonatally with coumestrol, a plant estrogen. J Toxicol Environ Health. 1985;15(1):51-61. doi:10.1080/15287398509530635. 